\title{
Student Teams Achievement Division Technique and Group Investigation Technique Through Lesson Study Enhancing Students Learning Outcomes
}

\author{
W.M.V Cahyanti Candradewi1 ${ }^{1}$ I Kt. Dharsana², I Md. Tegeh ${ }^{3}$ \\ ${ }^{1}$ Primary School Teacher Education Study Program, Ganesha University of Education, Indonesia \\ ${ }^{2}$ Counseling Guidance Study Program, Ganesha University of Education, Indonesia \\ ${ }^{3}$ Educational Technology Study Program, Ganesha University of Education, Indonesia
}

\section{A RTICLEINFO \\ Article history: \\ Received 2 Juni 2020 \\ Received in revised form \\ 12 Juli 2020 \\ Accepted 10 Agustus 2020 \\ Available online 28 Agustus 2020 \\ kata kunci: \\ Hasil Belajar, teknik STAD \\ dan GI, Lesson Study \\ keywords: \\ Learning Outcomes, STAD \\ and GI techniques, Lesson \\ Study}

\begin{abstract}
A B S T R A K
Ditemukannya Hasil belajar rendah dalam penelitian ini, maka dari itu Penelitian ini bertujuan untuk mengetahui efektivitas teori kontruktivisme dengan teknik Student Teams Achievement Division dan teknik Group Investigation melalui Lesson Study terkait pembelajaran tematik kelas V SD. Penelitian ini yaitu eksperimen semu dengan rancangan penelitian desain Rendomize Control Trials (RCTs). Populasi penelitian ini adalah siswa kelas VB berjumlah 26 orang. 13 orang siswa kelas VB sebagai kelompok eksperimen dan 13 orang siswa kelas VB sebagai kelompok kontrol. Pemerolehan data dikumpulkan dengan instrumen tes pilihan ganda sebanyak 30 soal. Data yang telah dikumpulkan dianalisis menggunakan statistik deskriptif dan Independen Sample t-test. Berdasarkkan hasil penelitian setelah dilakukan uji hipotesis menggunakan SPSS 25.00 for Windows pada tabel keputusan diperoleh nilai Sig. (2-tailed) $=0,005$ yang artinya nilai signifikansi $(2$-tailed $)<0,05(0,005<0,05)$, maka $\mathrm{H}_{0}$ ditolak dan $\mathrm{H}_{1}=$ diterima. Ini berarti hasil penelitian menunjukkan bahwa terdapat pengaruh signifikan pada kelompok eksperimen yang diajarkan dengan
\end{abstract} teknik Student Teams Achievement Division dan teknik Group Investigation melalui lesson study dengan kelompok kontrol yang dibelajaran guru seperti biasa pada hasil belajar siswa. Dengan demikian dapat disimpulkan bahwa teori konstruktivisme dengan teknik Student Teams Achievement Division dan teknik Group Investigation lesson study efektif meningkatkan hasil belajar tematik siswa kelas VB.

\section{A B S T R A C T}

The finding of learning outcomes is low in this study; therefore, this study aims to determine the effectiveness of constructivism theory with the Student Teams Achievement Division technique and Group Investigation techniques through Lesson Study related to thematic learning in fifth-grade elementary school. This research is a quasi-experimental research design with Randomized Control Trials (RCTs). The population of this research is 26 students in VB class. 13 VB class students as an experimental group and 13 VB class students as a control group. Obtaining data was collected with 30 multiple choice test instruments. Data collected were analyzed using descriptive statistics and an Independent Sample t-test. Based on the results of the study after testing the hypothesis using SPSS 25.00 for Windows in the decision table the value of Sig. (2-tailed) $=0.005$ which means the significance value $(2$-tailed) $<0.05(0.005<0.05)$, then $\mathrm{H} 0$ is rejected and $\mathrm{H} 1=$ accepted. This means that the results of the study indicate that there is a significant influence on the experimental group taught by the Student Teams Achievement Division technique and the Group Investigation technique through lesson study with a control group that the teacher learns as usual on student learning outcomes. Thus, it can be concluded that the theory of constructivism with the Student Teams Achievement Division technique and Group Investigation lesson study techniques effectively improve the thematic learning outcomes of VB grade students.

\section{Introduction}

Every human being essentially cannot be separated from education for his survival, especially in the current era of globalization, education is one of the important sectors in development in every country. In Indonesia, the functions and objectives of the ongoing education implementation have been clearly described in (PP NO 19, Tahun 2005) in chapter II articles 3 and 4 which states that. "The National Education Standards serve as the basis for planning, implementing, and supervising education in the context of realizing quality national education. In this regard, education has a very

Copyright (C) Universitas Pendidikan Ganesha. All rights reserved.

${ }^{1}$ Corresponding author.

E-mail addresses: virgholiamita@gmail.com (Cahyanti) ${ }^{1}$, profdarsana@yahoo.com (Dharsana) ${ }^{2}$,

imadetegehderan@yahoo.com (Tegeh) ${ }^{3}$ 
important role in realizing what the government has outlined, namely education plays a role in shaping students to become human beings who believe, fear God Almighty, have a noble character, are independent, knowledgeable, responsible, obey the law and become democratic citizens through planned activities (PP No. 19 Tahun 2005). To realize what the government has outlined and also formulate steps to achieve the achievement that teachers must take to achieve national education goals as described in the Chapter 19 Process Standards, which states that. "The learning process in educational units is carried out in an interactive, fun, challenging manner, motivates students to participate actively and provides sufficient space for creativity and independence initiatives according to the talents of interest and physical development and psychology of students". In the learning process, educators must be able to provide examples to students because, in the eyes of students, harrowing should be digested and imitated. Each education unit plans the learning process, implements the learning process, assesses the learning outcomes, and supervises the learning process for an effective and efficient learning process (PP NO.19 Tahun 2005).

In Indonesia, there have been several changes in the curriculum which are of course adjusted to the conditions of the demands of the times. Various efforts have been made by the government to improve the quality of education such as refining the Curriculum from the Competency-Based Curriculum (KBK) to the KTSP Education Unit Level Curriculum and at this time the 2013 Curriculum has been implemented In the learning process for the elementary school level in the 2013 Curriculum with its characteristics realizing a character education and implemented using a scientific approach. Daryanto (in Fadhilaturrahmi, 2017) states that learning with the scientific approach is a learning process designed in such a way that students actively construct concepts, laws, or principles through the stages of observing, formulating problems, proposing or formulating hypotheses, collecting data with various techniques, analyzing data, drawing conclusions and communicating the concept, law or principle found. The scientific approach is centered on the theme so that the material in each subject can be developed based on the competencies inherent in the web of themes. Meanwhile, Habibah (in Lisnani, 2019) said that to improve the quality of education, it is not only necessary to improve the curriculum but also the role of teachers and students in lessons that are needed to create learning success. With curriculum changes, it must be followed by improving the quality of teachers as the spearhead in the learning process who is responsible for organizing learning in schools to improve the quality of education, especially learning outcomes.

However, what happens in the field or real conditions at school is very concerning. From the results of observations on student learning outcomes is still low. The low student learning outcomes based on the results of interviews, observations, and document studies conducted on November 4, 2019, with class VB teachers at SD Negeri 1 Baktiseraga can be seen from the average value of MidSemester Deuteronomy which is still below the KKM (a passing grade). The results of the Middle Semester Deuteronomy in class VB students showed that the average score of students in Civics with KKM 75 was 65.08 with 6 students who had reached the KKM. Then, the average score of students in Indonesian lessons with KKM 70 is 63.62 with students who have reached KKM as many as 10 people. Meanwhile, the average score of students in Mathematics with KKM 68 is 51.15 with 2 students who have reached the KKM. The average score in science subjects with KKM 70 is 64.96 with 14 students who have reached KKM. The average score of students in social studies with KKM 70 is 50.38 with 3 students who have reached the KKM. After the assessment was carried out, it was found that the learning process in the classroom was still less varied, the teacher still used the lecture, question and answer method, assignment or homework (PR) and the use of media was still minimal. This of course will cause students to become; 1) lack of concentration and active participation in the learning process, 2) low learning motivation, students prefer to play in the learning process, 3) students are less capable of solving problems in learning. So that it will affect student learning outcomes and the quality of learning is low.

Facing the conditions mentioned above, it is necessary to apply various types of approaches, strategies, learning techniques, and application of learning theories. One of the learning theories that is suitable for use is the constructivism learning theory. Constructivism learning theory is a philosophy of knowledge that emphasizes that knowledge is a construction of oneself. Constructivism learning theory itself can be developed into several learning techniques that can be used to overcome the problem of low student learning outcomes, namely the Student Teams Achievement Division technique and the Group Investigation technique through Lesson Study. The similarities in this technique are carried out in groups to interact and require students to work together and actively communicate. This is in line with the opinion of Piaget and Vygotsky who emphasized the importance of interaction with peers through the formation of study groups because students are allowed to actively express their thought of ideas to their friends (Ariztasari, 2018) The 
Student Teams Achievement Division learning technique is the simplest learning technique done in groups, where students are taught to work together to exchange information with groups to improve student academic achievement. According to Robert E. Slavin (Samja, 2017). While (Inapi, 2018) revealed that the Student Teams Achievement Division learning technique is a technique that conditions students to learn and form their knowledge based on the experience and cooperation of each student in their group to complete the assignments that have been given to them. This technique trains students to work together and be responsible and the teacher as a facilitator to organize and supervise learning. Slavin (Tendrita \& Sari, 2020) suggests three concepts in the Student Teams Achievement Division technique, namely 1) Group award, given if the group can achieve predetermined learning criteria. 2) Individual responsibility, meaning that the success of the team depends on the individual learning of all team members, and the same chance of success, meaning that all students contribute to their team by improving their performance from the previous one. Furthermore, there was an opinion regarding a technique that was collaborated with Student Teams Achievement, namely Group investigation. (Wahyuningsih, 2017) suggests three concepts in the Student Teams Achievement Division technique, namely 1) Group award, given if the group can achieve predetermined learning criteria. 2) Individual responsibility, meaning that the success of the team depends on the individual learning of all team members, and the same chance of success, meaning that all students contribute to their team by improving their performance from the previous one. Furthermore, there was an opinion regarding a technique that was collaborated with Student Teams Achievement, namely Group investigation (K. Dharsana, 2014) The teacher can build knowledge about how to improve management skills and the quality of interaction through collaborative learning. Collaborative coaching of the teaching profession can be through Lesson Study. Therefore, the application of the Student Teams Achievement Division technique and the Group Investigation technique through Lesson Study is very suitable to be used as an alternative to the existing problems because basically according to the explanation of the technique, it is related, namely the application of group learning where there is a process of collaboration, mutual exchange information and students learn actively and communicatively.

This research is supported by (Yuniarti, et., al.., 2018) which states that the Student Teams Achievement Division technique can improve student learning outcomes. This is based on the application of this technique, there is a change in the behavior of students, namely students becoming active, and increasing student learning outcomes. This research is also supported by (Dewi, Manuaba, \& Suniasih, 2018) because it is proven that the application of Group Investigation techniques can improve student learning outcomes. Because this technique emphasizes student participation and activities to explore their knowledge so that it can improve student learning outcomes. However, Warpala (Budiastra, Sudana, \& Arcana, 2015) researched the title "The influence of different learning approaches and cooperative learning strategies on understanding and critical thinking skills in elementary science learning". The results of his research showed that the Group investigation and Student Teams Achievement Division techniques had a significantly different impact on critical thinking skills, the type of Group investigation was more effective in achieving critical thinking skills than Student Teams Achievement Division. Furthermore, this research is supported by (Putra, Margunayasa, \& Wibawa, 2019) which states that learning with lesson study-based Group Investigation techniques has an effect on the mastery of science concepts for fourth-grade students in semester II at SD Gugus XIV, Buleleng District, 2017/2018 academic year. With a strong concentration on lesson study, namely planning, implementation, and reflection.

Based on the explanation above, it is necessary to conduct an experimental study with the title "The Effectiveness of Constructivism Learning Theory with Student Teams Achievement Division Techniques and Group Investigation Through Lesson Study to Improve Learning Outcomes". The purpose of this study was to determine the significant effect on the experimental group that was taught using the Student Teams Achievement Division technique and the Group Investigation technique through Lesson Study with a control group that was taught using conventional learning in class VB students at SD Negeri 1 Baktiseraga.

\section{Research Method}

This research is a quasi-experimental research type (Quasi-Experimental Design) because the experimental unit is a class and there is a control group but it cannot fully function to control variables outside the experiment. With the research design randomized control trials (RCTs), the most robust design to evaluate is used to show that the intervals used are feasible. In Purwoko, et., al., (2016:55) Randomized in RCTs means that research subjects have the same chance of being 
randomly assigned to the experimental group as well as the control group. The term control trials mean that there are other actions as control trials. The research design used only one class which was divided into two groups. One experimental group and one control group, with a randomized Control Trials (RCT) design. Students are first given a pre-test to find out the students 'initial understanding of the material to be taught, the questions given to the VB class students are related to thematic 8. After knowing the students' initial understanding, then the experimental group is given learning using Student Teams Achievement Division techniques and techniques. Group Investigation and the control group were given the usual treatment by the teaching teacher. After both groups were given treatment related to theme 8 , both groups were given a post-test. While the population in this study amounted to 26 students, for example with alphabets in the form of a, b, c, d, e, f, g, h, i, j, k, l, m ... and so on, up to 26 students. Then it was made into 2 groups, namely the experimental group and the control group. In determining the number of populations in the experimental group and the control group, the researcher did it by randomized (random). The experimental group obtained students randomly, namely b, f, h, i ... up to 13 people, and the control group was randomized, for example, students e, j, $\mathrm{k}, \mathrm{n}$... totaled 13 people. This population uses simple random data collection (simple random sampling), in (Budiarto, 2004) "Simple random sampling is sampling in such a way that each basic unit (individual) has the same opportunity to be taken as a sample." This study collected data using objective tests (multiple choice) of 30 items. The objective test used in this study is a multiple-choice consisting of 4 answer choices (A; B; C and D), one of which has the correct answer. The score on this test is 1 (one) if the answer is correct, a score of 0 (zero) is given if the answer is wrong. The minimum score for verification of learning outcomes is 0 and the maximum score is 30 , so student scores range from 0 to 100 , in processing student learning outcomes scores from raw scores to standard scores using PAP (Benchmark Reference Assessment). Multiple choice objective tests are arranged with a grid that will provide information about each item that will appear and the test results will provide information in the form of data in the form of scores or intervals. Thematic learning outcomes are assessed in terms of the development of student knowledge. The test is made by using Revised Bloom Taxonomy as a reference, the learning outcome test is adjusted to the SK and KD of learning. This test instrument has been tested to ensure the quality is fit for research use. The feasibility of this instrument is through a validity test with an expert or expert in their field. The grid of student thematic learning outcomes can be seen in Table 1 below.

Table 1. Students' Learning Outcomes Blueprint

\begin{tabular}{|c|c|c|}
\hline Subject & Basic Competency & $\begin{array}{l}\text { PROBLEM INDICATORS } \\
\text { Cognitive Level (C) }\end{array}$ \\
\hline $\begin{array}{l}\text { Bahasa } \\
\text { Indonesia }\end{array}$ & $\begin{array}{l}\text { 3.8. Describe the sequence of events or } \\
\text { actions contained in nonfiction text }\end{array}$ & $\begin{array}{l}\text { 3.8.1. Analyze the sequence of } \\
\text { events in a non-fictional text } \\
\text { paragraph (C4) }\end{array}$ \\
\hline Science & $\begin{array}{l}\text { 3.8. Analyze the water cycle and its impact on } \\
\text { earthly events and the survival of living things }\end{array}$ & $\begin{array}{l}\text { 3.8.1. Analyze the } \\
\text { events of the } \\
\text { water cycle on } \\
\text { earth (C4) }\end{array}$ \\
\hline $\begin{array}{l}\text { Social } \\
\text { Science }\end{array}$ & $\begin{array}{l}\text { 3.3. Analyzing the role of the economy in } \\
\text { efforts to improve people's lives in the } \\
\text { social and cultural fields to strengthen } \\
\text { the unity and integrity of the Indonesian } \\
\text { nation and its relationship with spatial } \\
\text { characteristics }\end{array}$ & $\begin{array}{l}\text { 3.3.1. Finding the role } \\
\text { of the economy } \\
\text { in the welfare of } \\
\text { society in the } \\
\text { social field (C4) }\end{array}$ \\
\hline $\begin{array}{l}\text { Civic } \\
\text { Education }\end{array}$ & $\begin{array}{l}\text { 3.3. Examining the socio-cultural diversity of } \\
\text { the community }\end{array}$ & $\begin{array}{l}\text { 3.3.1. Analyzing the } \\
\text { cultural } \\
\text { diversity of the } \\
\text { community } \\
\text { (C4)) }\end{array}$ \\
\hline $\begin{array}{l}\text { Art and } \\
\text { culture }\end{array}$ & 3.2. Understanding the tone & $\begin{array}{l}\text { 3.2.1. Determine the } \\
\text { types of tones } \\
\text { (C3) }\end{array}$ \\
\hline \multicolumn{2}{|c|}{ Total Questions } & 30 Questions \\
\hline
\end{tabular}


This study using a descriptive statistical analysis method, to determine the category of thematic learning outcomes of the experimental group and control group students. Descriptive statistical analysis was performed to find the mean (mean), middle data (median), large numbers of data (mode), variance, and standard deviation. Furthermore, data analysis was carried out using inferential statistics in the form of prerequisite tests to look for normality tests, homogeneity tests, and t-tests using SPPS 25.00 For Windows to find out the truth in the experimental group and the control group with different treatments.

\section{Result and Discussion}

The data in this study were students' thematic learning outcomes scores. The measurement of student thematic learning outcomes was carried out after the experimental group was taught the Student Teams Achievement Division technique and the Group Investigation technique through lesson study and the control group was taught by the teacher as usual. Data analysis was carried out in each group, namely the experimental group and the control group. The results of descriptive statistical data analysis are presented in Figure 1.

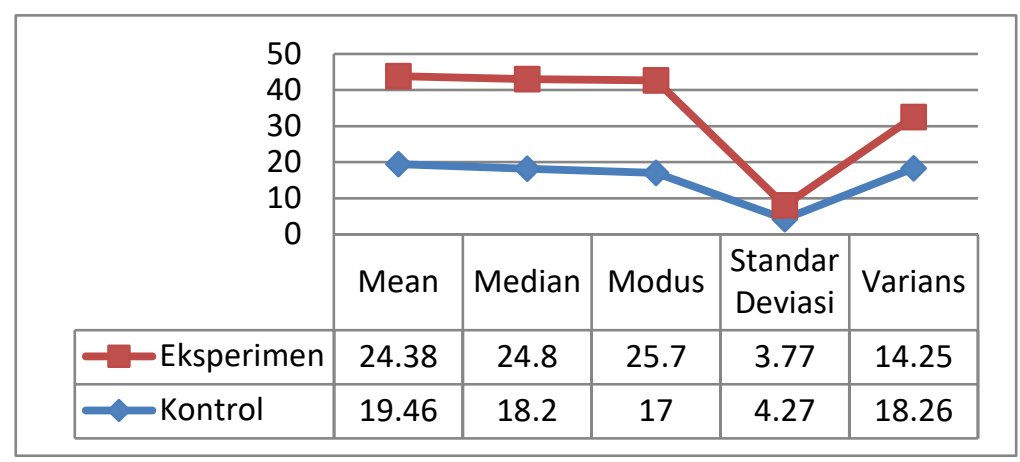

Figure 1. Graph of Data Analysis with Descriptive Statistics

In Figure 1, it is shown that the experimental group has a mean $=24.38$, median $=24.8$, and mode $=25.7$ this shows that the mean is smaller than the median and the median is smaller than the mode (Mo> Md> M ). Based on the thematic learning results in the experimental group, the average score that has been converted using the ideal average criterion (M1) and the ideal standard deviation (SD1) is obtained. 38 is classified as "very high" criteria. Whereas in the control group, the mean = 19.46 , median $=18.2$, and mode $=17$ shows that the mean is greater than the median and the median is greater than the mode $(\mathrm{Mo}<\mathrm{Md}<\mathrm{M})$. Based on the thematic learning outcomes of the control class, the average score that has been converted using the ideal average criterion (M1) and the ideal standard deviation (SD1), the conversion results are obtained from the average score of thematic learning results for the control group $=19.46$ classified as category " high". Before testing the hypothesis, first, perform a prerequisite test which includes a normality test and a homogeneity test. The prerequisite test, which is used to find scores for students' thematic learning outcomes, can be seen in Table 2.

Table 2. Normality test and variance homogeneity test using SPSS 25.00 For Windows

\begin{tabular}{|c|c|c|c|c|c|c|}
\hline \multicolumn{7}{|l|}{ Tests of Normality } \\
\hline \multirow{2}{*}{ Post-test } & \multicolumn{3}{|c|}{ Kolmogorov-Smirnova } & \multicolumn{3}{|c|}{ Shapiro-Wilk } \\
\hline & Statistic & df & Sig. & Statistic & Df & Sig. \\
\hline Student $\quad$ Teams & .183 & 7 & $.200^{*}$ & .929 & 7 & .545 \\
\hline \multicolumn{7}{|l|}{ Achievement Division } \\
\hline \multicolumn{7}{|l|}{1} \\
\hline \multicolumn{7}{|l|}{ ] } \\
\hline Group Investigation & .172 & 6 & $.200^{*}$ & .912 & 6 & .452 \\
\hline Kontrol & .172 & 13 & $.200^{*}$ & .951 & 13 & .608 \\
\hline \multicolumn{7}{|l|}{ Tests of Homogeneity } \\
\hline & Levene $S$ & atistic & df1 & df2 & Sig. & \\
\hline Post-test & .551 & & 1 & 24 & .465 & \\
\hline
\end{tabular}


The results of calculating the normality test with the help of SPSS 25.00 for windows in the experimental group that was taught using the Student Teams Achievement Division and Group Investigation techniques through lesson study are seen in the Shapiro-wik table with a significance value greater than 0.05 . Therefore, the data is normally distributed. Furthermore, the prerequisite test of variance homogeneity was carried out. The results of the homogeneity test of variance using Levene's Test on the learning outcomes of the thematic approach with a significant value $>0.05$, the data distribution is homogeneous, but if the significant value $<0.05$, the data distribution is not homogeneous. The results of the homogeneity test of data variance that have been analyzed from learning outcomes in the experimental and control groups are a significant value of 0.465 so that the data is homogeneous because the significant value is $0.465>0.05$. After the normality and homogeneity test, then the hypothesis test was carried out using an independent sample t-test (not correlated). Independent test sample t-test using SPSS 25.00 for Windows decision requirements by looking at 2-tailed, where the significance value (2-tailed) $<0.05$ indicates a significant difference between the experimental group and the control group. This shows that there is a significant effect on the differences in the treatment given to the experimental group. Hypothesis Test Results are presented in Table 3.

Table 3. Hypothesis Test

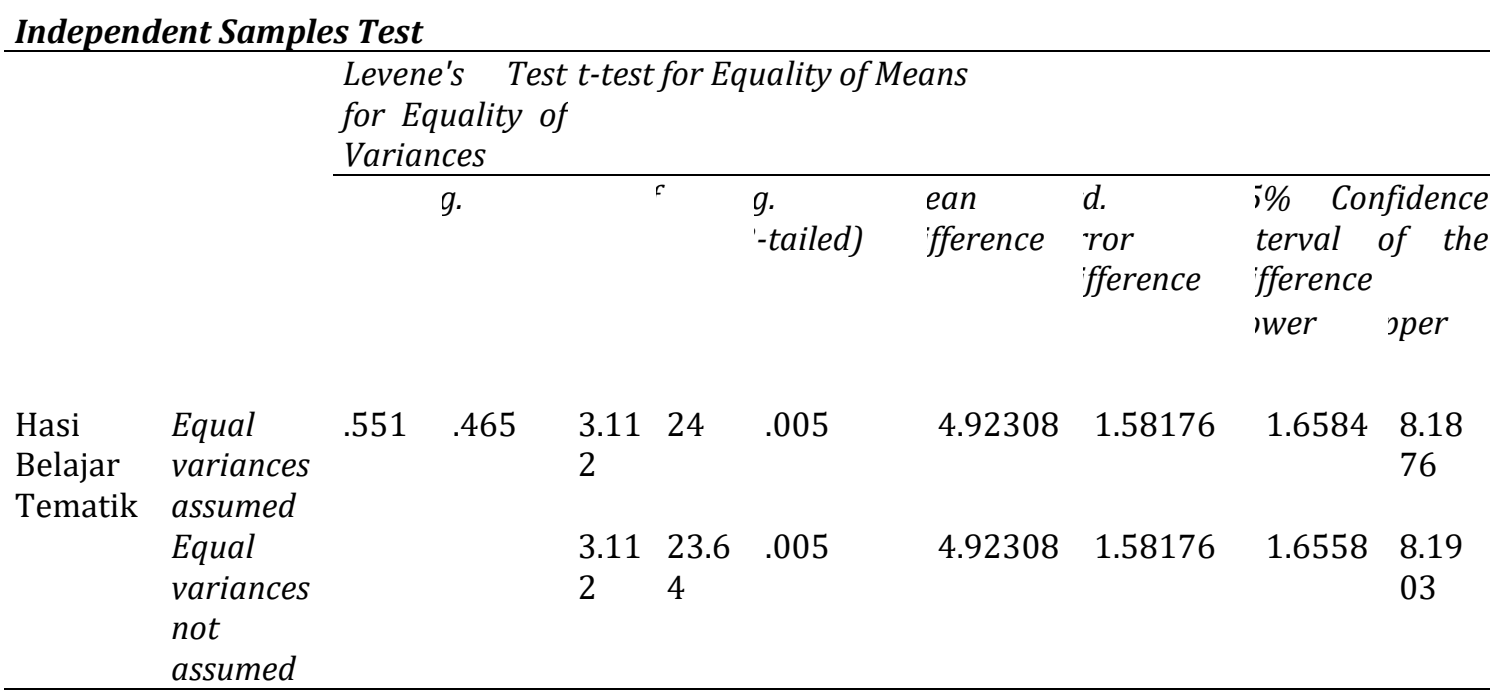

In Table 3, it is found that the t-test results obtained are 2 -tailed $=0.005$, meaning that the 2 tailed value $=0.005<0.05$, then $\mathrm{H} 0$ is rejected and $\mathrm{H} 1$ is accepted, which means that there is a significant effect of treatment, it can be interpreted that: significant in the experimental group that was taught with the Student Teams Achievement Division technique and the Group Investigation technique through lesson study with a control group taught by the teacher as usual on the learning outcomes of class VB students at SD Negeri 1 Baktiseraga. Based on these findings, the Student Teams Achievement Division technique and the Group Investigation technique through lesson study has a significant effect on the thematic learning outcomes of the VB grade students of Baktiseraga 1 Elementary School.

Based on the results of the study, it was found that the differences in learning outcomes in the thematic approach between students in the experimental group and the control group were due to differences in treatment in the learning process. Differences in treatment in the learning process can occur due to several things. First, the learning process is taught using the Student Teams Achievement Division technique and the Group Investigation technique through Lesson Study, namely: (1) with this technique it can improve student learning outcomes, (2) students play an active role in participating in learning (3) students can relate experiences that have been obtained by learning that students receive. The Student Teams Achievement Division technique and the Group Investigation technique through Lesson Study can provide new experiences for students to explore knowledge so that they can improve understanding. This learning technique is not teacher-centered but student-centered so that students are trained to foster independent, analytical, critical, creative, reflective, and productive thinking skills. In addition, with the formation of groups, students can develop an attitude of mutual understanding and democracy, an attitude of cooperation with group 
friends, and good communication between group members (Lasfeto, 2017). This, of course, was obtained from the results of research in class VB using the Student Teams Achievement Division technique and the Group Investigation technique through Lesson Study through several stages, namely.

First group formation. Heterogeneous group formation by distinguishing gender and level of student ability. In line with that (Suparmi, 2013) said that according to the Group Investigation technique and the Student Teams Achievement Division technique, several students were formed as members of small groups with different levels of ability. In completing group assignments, each student must cooperate, helping each other to understand the subject matter. Second planning. At this stage, the teacher delivers learning material and conveys the learning objectives to be achieved. At this stage, students begin to think about the next steps.

Third Investigation students actively collect information by looking for media or learning resources following the topic or material that has been presented. learning resources are not only found in student handbooks. This is according to the opinion of Mclsaac and Gunawardena (in Supriadi, 2017) that learning resources that are used are not only in a printed form such as textbooks, but in the form of educational radio, television, computer, e-mail, interactive video, satellite communication, and multimedia computer technology to increase interaction and the occurrence of feedback with participants students.

Fourth, namely organizing or students with groups investigating problems, in solving student problems it is necessary to convey ideas, exchange opinions between-group friends. At this stage, students must be responsible for their group of students not just sitting there without contributing. This is in line with the opinion of (Yuniarti et al., 2018) In general, group success is determined by individual contributions. This is done so that all group members are responsible for learning and therefore students are not selfish. This of course will be able to instill the concept in students because students have directly expressed the contents of their thoughts, the learning process will be meaningful and can improve student learning outcomes.

The fifth is presentations and giving quizzes to groups. This aims to improve student communication or increase student confidence to present to the class the results of their group work. This will make students more actively communicative in addition to giving students quizzes competing to get the opportunity to answer the quizzes that are given, this will certainly make learning active and fun as well as competition between students in groups. This is in line with the opinion (Kirom, 2017) that learning activities, all students must be active in group activities and how far students can participate in activities will be determined by how far the activities have the freedom and can arouse the spirit of the student competition.

The sixth is giving awards. This stage is certainly eagerly awaited by students because they will be very happy with the awards that have been given. This will motivate students to learn so that they can get the award. Increased student activity in the learning process due to encouragement and motivation to learn. In accordance with the opinion of Medyasari, et al (in Wicaksono, Sagita, \& Nugroho, 2017) is a learning technique that requires students to be active and participate in the learning process with this technique to explore/find information learned with the group with the tools and materials that have been provided. Therefore this technique is very appropriate for improving learning outcomes. Learning outcomes are things that are obtained by students after participating in learning activities in achieving learning goals itself which provide changes in behavior, both knowledge, understanding, attitudes, and skills of students so that they become better than before. (Irawan \& Ningrum, 2016).

The effect of learning outcomes between groups of students who take learning with the Student Teams Achievement Division technique and the Group Investigation technique through Lesson Study with students who take conventional learning is caused by several factors as follows. First, the implementation of learning using the Student Teams Achievement Division technique and the Group Investigation technique through Lesson Study makes students active in participating in learning and takes responsibility in groups. Through the lesson study at the planning stage together with the VB homeroom teacher, they compiled the grids, lesson plans, question instruments that had been tested beforehand by experts in the field of these subjects. Planning consists of analyzing needs and learning problems. Second, the combination of the Student Teams Achievement Division technique and the Group Investigation technique through Lesson Study gives a different impression to this learning, because there are three stages: first planning, second implementation, and third reflection. The Student Teams Achievement Division technique and the Group Investigation technique through Lesson Study look better than conventional learning because in this learning all students are serious about listening to the learning and are very enthusiastic in participating in the 
learning, this is proven by all students answering the LKS correctly. In addition, in discussions, students began to show a responsible attitude, had the courage to express their opinions, and answer questions based on LKS. Information in learning can stimulate students' thoughts, feelings, attention, and willingness so that it can encourage the learning process in students.

Isjoni (in Esminarto et al., 2016) The effect of learning outcomes between groups of students who take learning with the Student Teams Achievement Division technique and the Group Investigation technique through Lesson Study with students who take conventional learning is caused by several factors as follows. First, the implementation of learning using the Student Teams Achievement Division technique and the Group Investigation technique through Lesson Study makes students active in participating in learning and takes responsibility in groups. Through the lesson study at the planning stage together with the VB homeroom teacher, they compiled the grids, lesson plans, question instruments that had been tested beforehand by experts in the field of these subjects. Planning consists of analyzing needs and learning problems. Second, the combination of the Student Teams Achievement Division technique and the Group Investigation technique through Lesson Study gives a different impression to this learning, because there are three stages: first planning, second implementation, and third reflection. The Student Teams Achievement Division technique and the Group Investigation technique through Lesson Study look better than conventional learning because in this learning all students are serious about listening to the learning and are very enthusiastic in participating in the learning, this is proven by all students answering the LKS correctly. In addition, in discussions, students began to show a responsible attitude, had the courage to express their opinions, and answer questions based on LKS. Information in learning can stimulate students' thoughts, feelings, attention, and willingness so that it can encourage the learning process in students.

Isjoni (in Tembang, Harmawati, \& Rahajaan, 2019) stated that the Group Investigation technique is a group-based learning technique that provides opportunities for students to discuss, think critically, and be responsible for the learning. So, this technique will be very fun and able to arouse students' thinking to think not passively. According to Sharan \& Shumarmi (in Prasetyo Widyanto, 2017), The advantages of the Group Investigation technique are that students can discuss and develop ideas, students learn more effectively, students can increase their social interaction, and can encourage students to participate actively, and Group Investigation techniques can improve student learning achievement. Therefore, the Student Teams Achievement Division and Group Investigation techniques are very appropriate in the learning process through lesson study. Whereas Lesson Study is not a learning method or strategy, but Lesson Study can be applied in various learning methods or strategies according to the situation, conditions, and learning problems faced by the teacher (Dharsana, Suarni, \& Mahendra, 2020).

The supporters of this previous research by (Suarni \& Sulasih, 2017) that activities in learning with the Student Teams Achievement Division technique are more active and creative. This is based on responsibility, which requires them to be active, to find a solution to each of these problems. With the increase in student activity in finding solutions to each given problem, it will directly lead to an increase in student learning outcomes. Along with that, the results of this study are also supported by the findings (Andi, Arsana, Jampel, \& Kusmariyatni, 2017) namely the experiment that was applied by the Student Teams Achievement Division technique resulted in Mean $=19.84$, which was greater than the control group, Mean $=17$. This shows that the Student Teams Achievement Division technique affects student social studies learning outcomes. The cause, namely the Student Teams Achievement Division technique assisted by concept maps, involves students directly and actively in the social studies learning process. Apart from the findings using the Student Teams Achievement Division technique, it is also supported by research conducted by (Ariawan, et., al.., 2016) namely the experiment that was applied by the Student Teams Achievement Division technique in achievement Mean $=19.84$, which was greater than the control group, Mean $=17$. This shows that the Student Teams Achievement Division technique affects student social studies learning outcomes. The causes, namely the Student Teams Achievement Division technique assisted by concept maps, involve students directly and actively in the social studies learning process. Apart from the findings using the Student Teams Achievement Division technique, it is also supported by research conducted by (Sidabutar \& Dharsana, 2018) which is seen from the use of Lesson Study, through the lesson study setting proves that the effect on learning outcomes. This is due to the concept of teacher collaboration which can give a new impression so that students become enthusiastic in the learning process. (Sudiasih, Wibawa, \& Margunayasa, 2020) also supports this finding that there is a significant influence on the learning model group investigation through lesson study on the mastery of the science concept of even semester IV grade SD students in Cluster VII, Kubutambahan District, 
Buleleng Regency, 2018/2019 Academic Year. This can be seen from the average value of the experimental group with the control group, namely 19.55>14.55.

Based on the explanation of the research results above, it can be seen that there are significant differences in thematic learning outcomes of students who are taught using the Student Teams Achievement Division technique and the Group Investigation technique through lesson study with students who are not taught using the Student Teams Achievement Division technique and the Group Investigation technique through lesson study on VB class at SD Negeri 1 Baktiseraga.

The research implication is to determine the logical consequence, namely, the selection of a learning model appropriately has an impact on student learning outcomes. This research proves that the Student Teams Achievement Division technique and the Group Investigation technique through Lesson Study which are used as a material in carrying out treatment in elementary schools' effect when applied in teaching and learning process activities. The use of these techniques makes learning interesting and not boring. In this research carried out obtained results that are useful as input for teachers to improve the learning process so that students' thematic learning outcomes are as expected. Therefore, this technique can be applied by teachers in further learning because it has been proven to affect student learning outcomes to increase.

\section{Conclusion}

Based on the research objectives, it was concluded that there was a significant influence on the experimental group that was taught using the Student Teams Achievement Division technique and the Group Investigation technique through lesson study with the Control group taught by the teacher as usual on the learning outcomes of VB class students at SD Negeri 1 Baktiseraga. Based on the hypothesis test through data analysis using the t-test using SPSS 25.00 for Windows, which states that $\mathrm{H} 0$ is rejected and $\mathrm{H} 1$ is accepted, which means that there is a significant effect of giving treatment, it can be interpreted that: There is a significant effect on the experimental group that was taught using the Student Teams technique. Achievement Division and Group Investigation techniques through lesson study with a control group taught by the teacher as usual on the learning outcomes of class VB students at SD Negeri 1 Baktiseraga.

Suggestions that can be submitted Based on the above conclusions are as follows. For students, it is recommended to take part in learning actively, responsibly, and build good interactions between students in learning activities and be able to build their knowledge, be competitive, and can improve student thematic learning outcomes. Teachers, it is advisable to apply innovative and fun learning techniques. to help students understand the material well and students are not passive. To the principal, based on the results of this study the principal is expected to always improve educational facilities, and be able to encourage teachers to try to apply learning techniques that are in accordance with student characteristics ., and To other researchers, it is suggested that this study be used as a reference by paying attention to existing constraints and this research is used as a consideration for the improvement of the research to be carried out.

\section{References}

Andi, I. P., Arsana, B., Jampel, I. N., \& Kusmariyatni, N. (2017). Pengaruh model pembelajaran kooperatif tipe stad ips kelas IV SD Universitas Pendidikan Ganesha. (1). http://dx.doi.org/10.23887/ijpgsd.v5i2.11031

Ariawan, K. D., Jampel, I. N., \& Rati, N. W. (2016). Pengaruh Model Pembelajaran Kooperatif Tipe Group Investigation Berbasis Media Lingkungan Terhadap Hasil Belajar Ipa Siswa Kelas Iv Di Desa Sidetapa. E-Journal PGSD Universitas Pendidikan Ganesha, 4(1), 1-10. http://dx.doi.org/10.23887/ijpgsd.v4i1.6609

Ariztasari, I. (2018). Enhancing the Critical Thinking Ability of Events in Life through the Cooperative Model Think Pair Distribute VA Class at SDN Giwangan. Pendidikan Guru Sekolah dasar:DIDAKDITA, 1(June). https://doi.org/10.21831/didaktika.v1i1.28079

Budiarto, E. (2004). Metode Penelitian Kedokteran. Jakarta: Penerit Buku Kedokterann.

Budiastra, I. K., Sudana, D. N., \& Arcana, N. (2015). Pengaruh Model Kooperatif Tipe Gi ( Group Investigation ) Terhadap Keterampilan Berpikir Kritis Dalam Pembelajaran IPA Jurusan Pendidikan Guru Sekolah Dasar, FIP Universitas Pendidikan Ganesha. E-Journal PGSD, 3. http://dx.doi.org/10.23887/ijpgsd.v3i1.4812 
Dewi, P. P. Y., Manuaba, I. S., \& Suniasih, N. W. (2018). Pengaruh Model Pembelajaran Kooperatif Tipe Group Investigation Terhadap Hasil Belajar Ipa Siswa Kelas Iv Sekolah Dasar. Jurnal Penelitian Pendidikan Guru Sekolah Dasar, 6(11), 264-271. http://dx.doi.org/10.23887/ijee.v1i4.12957

Dharsana, I. K., Suarni, N. K., \& Mahendra, I. G. N. (2020). Efektivitas Konseling Behavioral dengan Teknik Modeling untuk Meningkatkan Self Autonomy melalui Lesson Study. Jurnal Ilmiah Bimbingan Konseling Undiksha, 10 (2), 87. 10.23887/iibk.v10i2.23281

Dharsana, K. (2014). Model-model, Teori, Teknik, Skill Bimbingan Konseling. Singaraja: Universitas Pendidikan Ganesha.

Esminarto, E., Sukowati, S., Suryowati, N., \& Anam, K. (2016). Implementasi Model Stad Dalam Meningkatkan Hasil Belajar Siwa. Briliant: Jurnal Riset Dan Konseptual, 1(1), 16. http://dx.doi.org/10.28926/briliant.v1i1.2

Fadhilaturrahmi. (2017). Penerapan Pendekatan Saintifik Untuk Meningkatkan Kemampuan Komunikasi Matematik Peserta Didik di Sekolah Dasar. EduHumaniora / Jurnal Pendidikan Dasar Kampus Cibiru, 9(2), 109. https://doi.org/10.17509/eh.v9i2.7078

Inapi, M. L. (2018). Pengaruh Model Pembelajaran Kooperatif Terhadap Motivasi Dan Hasil Belajar Siswa Pada Materi Sistem Koloid. Pembelajar: Jurnal Ilmu Pendidikan, Keguruan, Dan Pembelajaran, 2(1), 12. https://doi.org/10.26858/pembelajar.v2i1.4135

Irawan, F. J., \& Ningrum, N. (2016). Pengaruh Penggunaan Model Cooperative Learning Tipe Group Investigation (Gi) Terhadap Hasil Belajar Prakarya Dan Kewirausahaan (Pkwu) Siswa Kelas X Semester Genap Smk Negeri 1 Metro Tp 2015-2016. PROMOSI (Jurnal Pendidikan Ekonomi), 4(2), 61-68. http://dx.doi.org/10.24127/ja.v4i2.641

Kirom, A. (2017). Peran Guru Dan Peserta Didik Dalam Proses Pembelajaran Berbasis Multikultural. Al Murabbi, 3(1), 69-80. Retrieved https://jurnal.yudharta.ac.id/v2/index.php/pai/article/view/893

Lasfeto, A. R. (2017). Meningkatkan Hasil Belajar Ipa Melalui Model Group Investigation Berbantuan Video Pada Siswa Sekolah Dasar. Jurnal Penelitian Dan Pengembangan Pendidikan, 1(3), 1-7. http://dx.doi.org/10.23887/jppp.v1i3.12631

Lisnani, L. (2019). Pengaruh Model Pembelajaran Example Non Example Untuk Meningkatkan Hasil Belajar Tematik Bagi Siswa Kelas VI Sd. Jurnal Basicedu, 3(1), 76-82. https://doi.org/10.31004/basicedu.v3i1.81

Peraturan Perundang-undangan N0.19 Tahun 2005. (2005). Standar Nasional Pendidikan.

Prasetyo Widyanto. (2017). Penerapan Metode Pembelajaran Group Investigation Berbantuan Media Flanelgraf Untuk Meningkatkan Minat Dan Hasil Belajar Siswa Pada Mata Pelajaran Ipa. Jurnal $\begin{array}{llllll}\text { Pendidikan Dasar Nusantara, } & \text { Vol. } & \text { 3(No. } & 120 . & \text { h. }\end{array}$ https://ojs.unpkediri.ac.id/index.php/pgsd/article/view/708

Purwoko, B., Prawitasari, J. E., Atmoko, A., \& Handarini, D. M. (2016). Keefektifan Konseling Resolusi Konflik untuk Mengatasi Konflik Interpersonal pada Siswa Sekolah Menengah Atas. Jurnal Pendidikan Humaniora, $4(1)$ 53-63. http://journal.um.ac.id/index.php/jph/article/view/8206

Putra, P. G. N., Margunayasa, I. G., \& Wibawa, I. M. C. (2019). Pengaruh Model Pembelajaran Kooperatif Tipe Group Investigation (GI) Berbasis Lesson Study Terhadap Penguasaan Konsep IPA. Jurnal Pedagogi Dan Pembelajaran, 1(2), 84. http://dx.doi.org/10.23887/jp2.v1i2.19329

Samja, J. (2017). The Influence Of Cooperative Learning Model Student Team Â€Tm S Achievement Division ( Stad) For Student Results On The Subject Of Education History In Senior High School ( SMAN ) I Mata Pelajaran Pendidikan Sejarah Di Sekolah Menengah Atas Negeri ( SMAN ). Neliti:Pendidikan Sejarah FKIP-Universitas Riau, 4, 1-11. https://www.neliti.com/publications/189875/pengaruh-penggunaan-model-pembelajarankooperatif-tipe-student-teams-achievement

Sidabutar, G. S., \& Dharsana, I. K. (2018). Pengaruh Model Pembelajaran Kooperatif Tipe Two Stay Two Stray melalui Lesson Study terhadap Hasil Belajar IPA. E-Journal PGSD Mimbar PGSD, 6(2), 103-111. http://dx.doi.org/10.23887/jjpgsd.v6i2.19463 
Suarni, N. K., \& Sulasih, A. N. K. (2017). Penerapan Model Pembelajaran Kooperatif Tipe Stad Dengan Media Rotation Point Untuk Meningkatkan Hasil Belajar. International Journal of Elementary Education, 1. http://dx.doi.org/10.23887/ijee.v1i1.11436

Sudiasih, N. N., Wibawa, I. M. C., \& Margunayasa, I. G. (2020). Pengaruh Model Pembelajaran Group Investigation Melalui Lesson Study Terhadap Penguasaan Konsep Ipa Siswa. EduHumaniora / Jurnal Pendidikan Dasar Kampus Cibiru, 12(1), 25-36. https://doi.org/10.17509/eh.v12i1.18543

Suparmi, S. (2013). Pembelajaran Kooperatif dalam Pendidikan Multikultural. Jurnal Pembangunan Pendidikan: Fondasi Dan Aplikasi, 1(1), 108-118. https://doi.org/10.21831/jppfa.v1i1.1055

Supriadi. (2017). Pemanfaatan Sumber Belajar Dalam Proses Pembelajaran. Lantanida Journal, 3(2), 127. http://dx.doi.org/10.22373/lj.v3i2.1654

Tembang, Y., Harmawati, D., \& Rahajaan, J. P. (2019). Peningkatan Hasil Belajar IPA Siswa Melalui Penerapan Model Pembelajaran Kooperatif Tipe Group Investigation di Sekolah Dasar. Jurnal Ilmiah Sekolah Dasar, 3(2), 230-237. http://dx.doi.org/10.23887/jisd.v3i2.17643

Tendrita, M., \& Sari, A. P. P. (2020). Bioedusiana Team Achievement Divisions ( STAD ) Dipadu Rqa Berbasis Lesson. Bioedusiana, 5(1), 1-10. https://doi.org/10.34289/bioedu.v5i1.1427

Wahyuningsih, I. (2017). Pengaruh Model Pembelajaran Kooperatif Tipe Group Investigation Terhadap Hasil Belajar IPA. NATURAL: Jurnal Ilmiah Pendidikan IPA, 4(1), 26-33. http://dx.doi.org/10.30738/natural.v4i1.1861

Wicaksono, B., Sagita, L., \& Nugroho, W. (2017). Model Pembelajaran Group Investigation (Gi) Dan Think Pair Share (Tps) Terhadap Kemampuan Berpikir Kritis. Aksioma, 8(2), 1. https://doi.org/10.26877/aks.v8i2.1876

Yuniarti, D., Bagus, I., Surya, G., \& Wiyasa, I. K. N. (2018). Pengaruh Model Student Teams Achievement Divisions ( STAD ) Berbantuan Media Mind Mapping Terhadap Hasil Belajar IPS Siswa Kelas V SD Gugus III Kuta Utara Badung Tahun Ajaran 2017 / 2018. Mimbar PGSD Undiksha, 6(1), 1-7. http://dx.doi.org/10.23887/jjpgsd.v7i1.16970 